\title{
Analysis of the quality of life of medical students in Sobral - CE
}

\section{Análise da qualidade de vida dos estudantes de medicina em Sobral - CE}

Benedita Tatiane Gomes Liberato ${ }^{1}$. Ana Beatriz Gabriel Silva ${ }^{1}$. Ana Talita Vasconcelos Arcanjo ${ }^{1}$. José Jackson do Nascimento Costa ${ }^{1}$. Peter Richard Hall ${ }^{1}$. Mikkael Duarte dos Santos ${ }^{1}$.

1 Centro Universitário INTA (UNINTA), Sobral, Ceará, Brasil.

\begin{abstract}
Objective: The objective of the present study was to analyze the factors determining the quality of life of medical students in Sobral-CE and to compare them with the student's academic momentum. Method: This is an epidemiological, cross-sectional, quantitative and qualitative study, and a questionnaire was used to collect data from 308 medical students. The questionnaire chosen was the WHOQOL-BREF, which is a Quality of Life Assessment instrument, which will be composed of 20 questions, the answers follow a Likert scale (from 1 to 5, the higher the score the better the quality of life). Results: The students enrolled in the third semester showed a worse quality of life evaluation in all the domains evaluated, which coincided with poorer quality of life and with their own health. The fifth semester showed a better quality of life assessment in all domains. Conclusions: the statistically significant differences found between domains are due to the fact that students, when they enter college, have an enthusiasm that is lost over the years and a desire and search for mutual knowledge that goes away with the routine of the day by day.
\end{abstract}

Keywords: Quality of life. Medical students. Medical education.

\section{RESUMO}

Objetivo: O objetivo do presente estudo foi analisar os fatores que determinam a qualidade de vida de estudantes de medicina em Sobral-CE e compará-los com o momento acadêmico do estudante. Método: Estudo epidemiológico, transversal, quantitativo e qualitativo, tendo sido utilizado um questionário para coleta de dados de 308 estudantes de medicina. O questionário escolhido foi o WHOQOL-BREF, que é um instrumento de Avaliação da Qualidade de Vida, composto por 20 perguntas, as respostas seguem uma escala Likert (de 1 a 5, quanto maior a pontuação, melhor a qualidade de vida). Resultados: Os estudantes matriculados no terceiro semestre apresentaram pior avaliação da qualidade de vida em todos os domínios avaliados, coincidindo com pior qualidade de vida e com saúde própria. O quinto semestre apresentou melhor avaliação da qualidade de vida em todos os domínios. Conclusões: as diferenças estatisticamente significantes encontradas entre os domínios devem-se ao fato de os estudantes, quando ingressam na faculdade, terem um entusiasmo que é perdido ao longo dos anos e um desejo e busca de conhecimento mútuo que se afasta da rotina do dia a dia.

Palavras-chave: Qualidade de vida. Estudantes de medicina. Educação médica.

Autor correspondente: Benedita Tatiane Gomes Liberato, Rua Antônio Rodrigues Magalhães, 359, Dom Expedito, Sobral, Ceará. CEP: 62050-100. Telefone: +55 88 3112-3500. E-mail: tati_bianca@yahoo.com.br

Conflito de interesses: Não há qualquer conflito de interesses por parte de qualquer um dos autores.

Recebido em: 20 Set 2019; Revisado em: 09 Jul 2019; Aceito em: 09 Jul 2019. 


\section{INTRODUCTION}

The World Health Organization (WHO) defines quality of life as the individual's perception of life, addressing their culture and value system in which they live, and the relationship with their goals, expectations, standards and concerns. ${ }^{1}$ In this definition, it is perceived that the concept of quality of life is subjective, multidimensional, including positive and negative elements of evaluation. ${ }^{2}$

Expanding this concept to the medical students' lifestyle, determinants can be found for their quality of life. Initially, it is worth mentioning that undergraduate medical course is one of the most sought after among university selective processes. ${ }^{3}$ Thus, when inserted in the academic reality, medical students can have their quality of life compromised, such as lack of time and exhaustion in the early periods of intense study, as well as living with the suffering and pain that accompany the process of illness and death. ${ }^{4}$

Themedical educational environment includes several factors that contribute to learning such as lessons, other learning activities, teachers, and social relationships. The learning environment includes what is perceived or experienced by students and teachers, and stands out as a factor that can aggravate or mitigate stress among medical students. ${ }^{5}$ In this sense, the high academic performance of medical students greatly influences their quality of life and consequent professional competence. ${ }^{6}$

As an example, admission to Medical Schools is given through a college entrance examination and the workload required in these colleges is comprehensive. A good academic performance requires medical students to dedicate themselves exclusively to studies, with repercussions on their lifestyle, social relations and sleep. ${ }^{7}$

Systematic reviews and longitudinal studies of suicide literature, specifically in physicians, have identified that suicide rates among medical students are higher than those of the general population and other academic groups. ${ }^{8}$ A study in Germany in 2012 mentions that the suicide rate in physicians is three to five times higher than that of the general population. ${ }^{9}$

Thus, evaluating the quality of life of students is not much studied by institutions, but it is necessary to better understand the decisive factors in this quality and better intervene in these determinants in order to optimize student performance, reduce illness and increase personal satisfaction.

\section{METHODOLOGY}

\section{Study design}

This is an epidemiological, cross-sectional, quantitative study with the World Health Organization instrument for assessing quality of life in its short form (WHOQOL-bref).

\section{Sample characterization}

467 medical students were invited, corresponding to the total number of medical students enrolled in the private institution of higher education of Medicine of the city of Sobral - CE in the year 2017, but we finalized the reserach with only 308 medical students. The criteria of inclusion were: to be a student of the medical course of the University Center INTA - UNINTA. The exclusion criteria were incomplete or inadequate completion of the research questionnaire, lack of interest in participating in the research, and non-signing of the informed consent form.

\section{Data collection instruments}

For data collection, a questionnaire previously validated and used in several researches was used as a model to evaluate the quality of life of medical students, which will be adapted according to the objectives of this research. ${ }^{1,10}$ The questionnaire had a quantitative approach, which focuses on quantifying the quality of life of each student. The WHOQOL-BREF consists of 26 questions, with the first question referring to quality of life in general and the second to satisfaction with one's own health. The answers follow a Likert scale (from 1 to 5, that the higher the score, the better the quality of life). In addition to these two issues (1 and 2), the instrument has 24 facets, which comprise 04 domains, which are: physical, psychological, social relations and environment. This instrument can be used both for healthy populations and for populations affected by diseases and chronic diseases. In addition to the cross-cultural character, WHOQOL instruments value individual perception of the person and can assess quality of life in different groups and situations. ${ }^{10}$

\section{Data analysis}

For data analysis, means, standard deviation and confidence interval were calculated for each (as presented in the data collection) for each group (class). The data analysis was divided by semester.

Initially, to characterize the sample, the Shapiro-Wilk normality test was performed to evaluate if the sample had normal distribution and the Skewness-Kurtosis symmetry test to detect the normalization of the variables. Regarding the normality of the variables, it was observed that there is no statistical support to classify it as normal. Therefore, the research data should be submitted to non-parametric tests.

Investigate the differences between the groups, the Kruskal Wallis test was used, the Mann-Whitney test was used to compare the means between the groups, and to identify the correlation between the variables, the Pearson correlation coefficient was used, considering the $95 \%$ confidence interval, and significance level of $\mathrm{p}<0.05$.

\section{Ethical principles}

The study was conducted in accordance with the Declaration of Helsinki and the guidelines established by the Brazilian National Health Council - resolution number 466/2012, and approved by the Ethics in Research Committee from the University Center INTA - UNINTA under the protocol number 2.339.440. 


\section{RESULTS}

In the epidemiological analysis of the medical students of UNINTA that participated in the study, in the year 2017, the age, marital status and sex were evaluated to evaluate the composition of the groups of each semester.

In 2017, of the 467 students enrolled in the Faculty of Medicine of INTA - UNINTA University Center, 308 (65.95\%) participated in the study, of which $196(63.63 \%)$ women and $112(36.37 \%)$ were men. The percentage of participants per year of graduation was, respectively, $18.83 \%, 20.13 \%, 7.14 \%$, $7.14 \%, 3.90 \%, 19.80 \%, 12.67 \%, 10 \% 39 \%$. The average age of undergraduate students was 21.05 years, 20.68 years, 22.32 years, 20.68 years, 25 years, 23.20 years, 23.49 years, 22.97 years, equivalent to 22.42 years.

Thus, it can be seen that the majority of students from the first to the eighth semester were between 20 and 25 years of age, with a larger peak occurring in the fifth semester (Graphic 1).

Regarding marital status, the majority of the participating students were unmarried and the minority was divorced, the highest number of married were in the fifth semester (Graphic 2).

And in relation to sex, the majority of students were female, with a unanimous majority in all semesters (Graphic 3).

Graphic 1. Variable by age of undergraduate medical students. UNINTA, 2017.

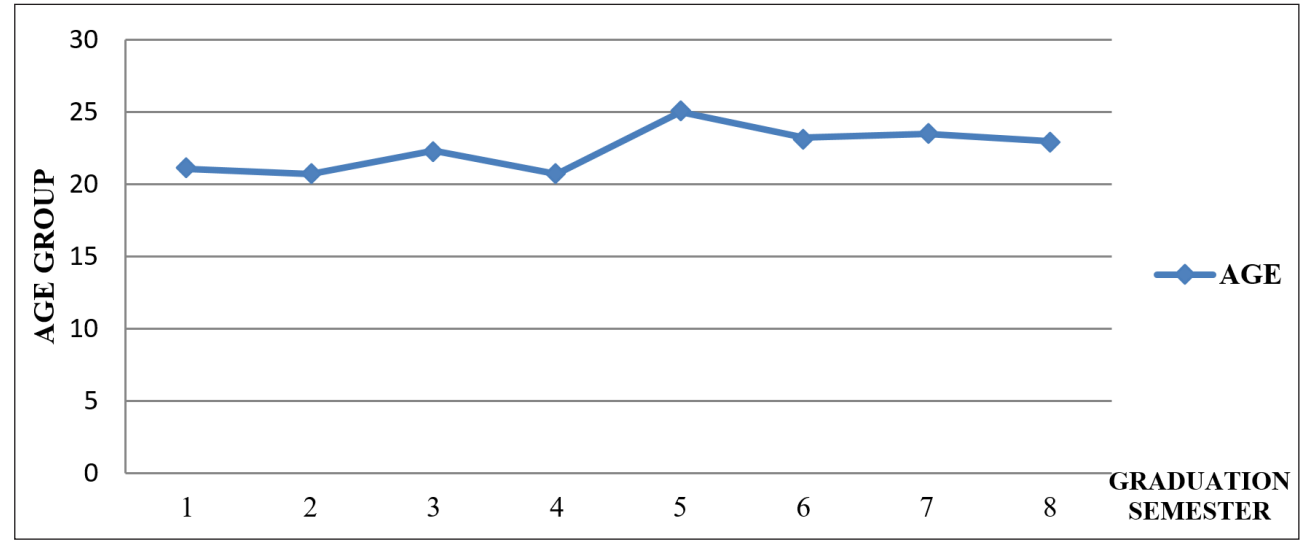

Graphic 2. Variable by marital status for undergraduate medical students. UNINTA, 2017.

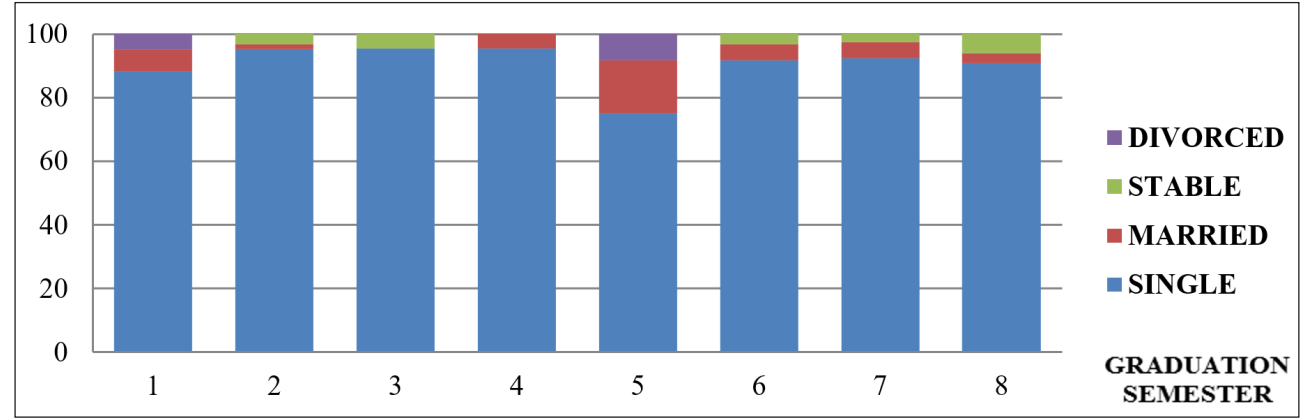

Graphic 3. Variable by sex per semester of undergraduate medical students. UNINTA, 2017.

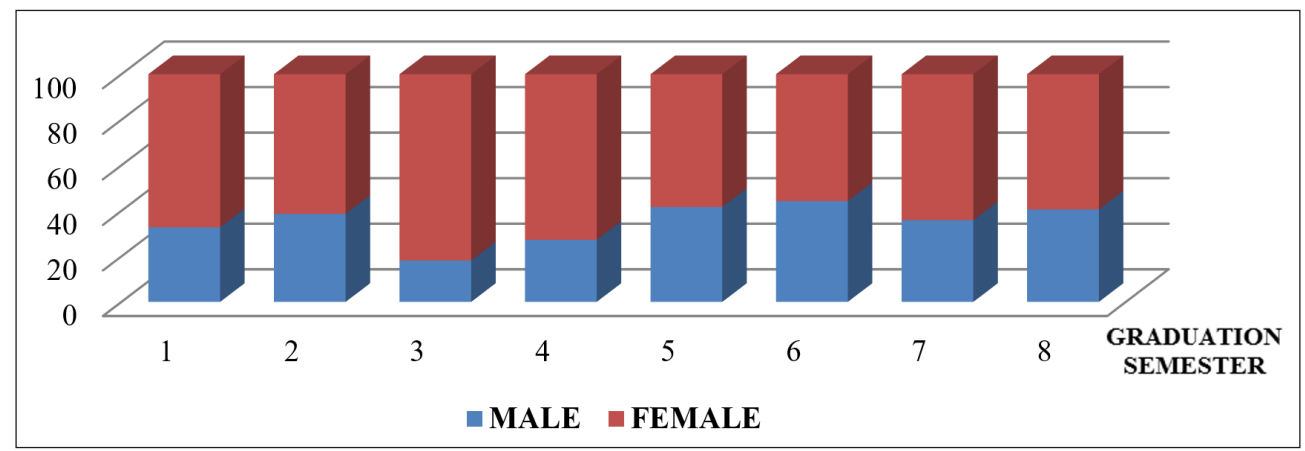


WHOQOL-bref has two general questions. The first one deals with the evaluation of the quality of life and it was pointed out that $74.63 \%$ of the students consider it good or very good, $21.97 \%$ regular and $3.40 \%$ classified that they need to improve in this question. The other question reflects the students' evaluation of their health conditions, it was pointed out that only $57.61 \%$ of the students were satisfied or very satisfied with their health, while $22.95 \%$ considered it regular and $19.44 \%$ that satisfaction with one's own health needs to improve.

Analyzing the general quality of life of UNINTA medical students in 2017, it can be noted that from the first (4.30 points) to the third semester ( 3.41 points) there is a decrease in quality, and in the third semester the worst evaluation. From the third to the fourth semester ( 3.73 points) there is a rise which is followed by a stability up to the seventh semester (4.02 points). In the eighth semester (4.28 points) there is a peak of evaluation of the general quality of life, which coincides with the evaluation of the first semester (Graphic 4).
And in relation to the evaluation of the satisfaction with the health itself, it is noticed that the students of the first semester (4,00 points) are the most satisfied. There is a fall until the third semester ( 2.68 points) where there is the worst satisfaction with one's own health. There is a remarkable rise to the fourth half (3.27 points), which remains stable until the fifth semester (3.25 points). From the fifth semester to the seventh (4.02 points) there is again a rise, followed by a slight decrease in the eighth semester (3.91 points) (Graphic 4).

In the first phase (3.59 points) and second (3.67 points), there is a similar evaluation of this domain by the academics, with a decrease in the third semester (3.07 points) which coincides with its worst rating. The quality improved positively until the fifth semester (3.63 points), remaining stable until reaching its peak in the seventh semester (3.96 points), which follows a slight drop in the eighth semester (3.71 points) (Graphic 5).

Graphic 4. Quality of life and health-related quality of life score (WHOQOL-bref) per semester of undergraduate medical students. UNINTA, 2017.

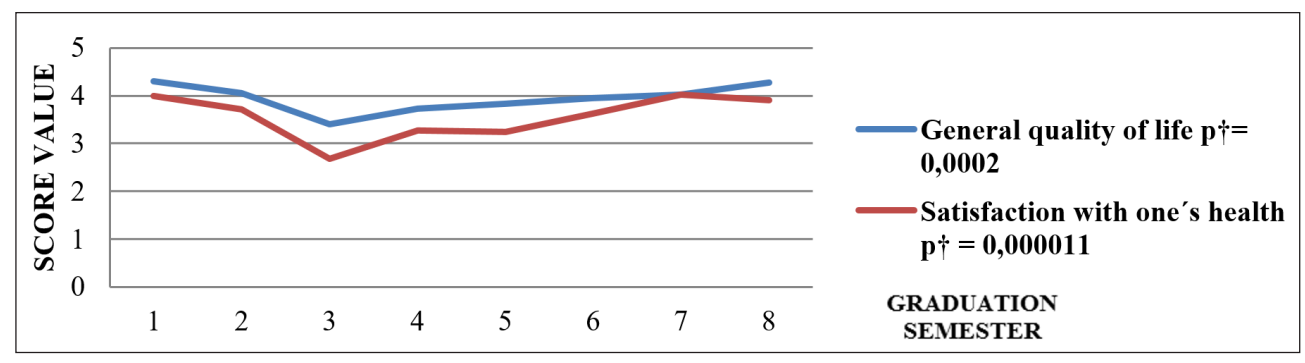

Graphic 5. Quality of life scores by domains (WHOQOL-bref) per semester of undergraduate medical students. UNINTA, 2017.

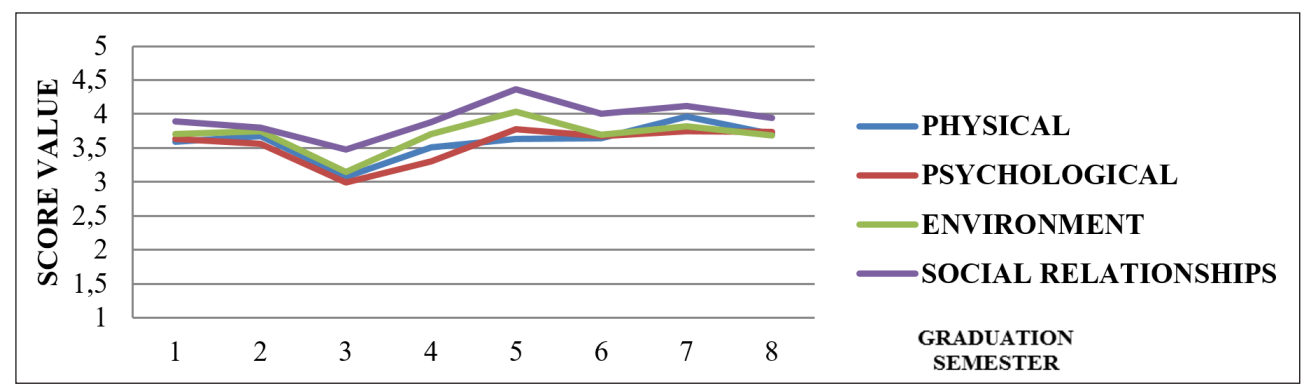

Analyzing the psychological domain in the graph, it is noticed that the students of the first (3.63 points) and second (3.56 points) semesters have a linearity of this quality, occurring a notable decrease in the third semester (2.99 points), which coincides with the worst quality evaluation of this domain. From the third to the fifth semester there is a rise, reaching its peak in the fifth semester (3.78 points). From the sixth (3.67 points) to the eighth (3.74 points) semester there are no discrepancies in this quality (Graphic 5).

Given the analysis of the quality of life in the field of environment in the chart, it is shown that the majority of students of the first semester has a quality of life in this regular domain with 3.71 points, which remains in the second half. There is a fall for quality that needs improvement in the third semester with 3.15 points. From it there is a rise of this quality of life, reaching its peak in the fifth semester with a score of 4.03 , in which the students have a good quality of life in this field. From the fifth to the sixth semester, with 3.70 points, there is a decline to a regular quality of life, which continues until the eighth semester which has 3.68 points. (Graphic 5).

Analyzing the quality of life of the domain of social relations in the graph, it is noticeable that from the first one 
(3.89 points) to the third semester (3.48 points) there is a decreasing evolution of the evaluation of the quality of this domain, being in the third semester its worse evaluation. From the third to the fifth semester ( 4.36 points) there is a rise in quality, which falls again in the sixth semester (4.01 points) and remains relatively linear until the eighth semester (3.94 points) (Graphic 5).

\section{DISCUSSION}

We evaluated the quality of life of medical students during the first semesters of the medical course in a private college in the interior of the state of Ceará. In the groups we found high scores on the WHOQOL-bref scores in the first two semesters, which declined from the third semester and started a progressive improvement in scores from the fourth semester, but failing to obtain the score obtained by the students in the first two graduation semesters. The hypothesis that the six-year medical course negatively affects the quality of life of medical students has been demonstrated in previous studies and ratified in the study by Chazan \& Campos, ${ }^{11}$ which showed a declining gradient in the WHOQOL-bref domains related to quality of life during the six years of graduation. It is also emphasized in our study that the third semester was considered to have the lowest index in all quality of life scores of the WHOQOL-bref by medical students.

Alves et $a 1^{12}$ also points out that it is common to observe that medical students, as well as physicians, have high rates of mental disorders. Although such students present psychological characteristics similar to those of students from other areas at the beginning of the undergraduate course, stress becomes an important factor with the beginning of medical training and contributes to the reduction of psychic well-being and the increase of anxiety, depression and burnout.

In the studied sample, female predominance (63.63\%) was observed. The predominance in females was not corroborated in another study carried out at the University of Brasília by Bampi et $a l^{13}$ (2013), which may justify the increasing presence of women in the labor market and the increasing insertion of women in the medical course with the passing of the years, which may indicate the feminization of the profession. But there is a of feminization of medicine in Brazil, the female presence being more frequent with the decrease of the age group, whereas the opposite happens with men. ${ }^{14}$

Regarding age, it is noticed that the majority of students from the first to the eighth semester are between 20-25 years old, which coincides with the study of Filho et $a 1,{ }^{15}$ since it also predominated youngsters up to 24 years old (76.4\%), following in fact the same national tendency, in which $73.7 \%$ of university students are in this age group.

Regarding marital status, the majority of the participating students were single and the minority was divorced. The highest number of married couples was observed in the fifth semester, which coincides with the study by Filho et $a l^{15}$ in which in the medical course of UERN $91.3 \%$ were single, resembling Firotti et $a l,{ }^{16}$ in which $98.7 \%$ have this marital status.

In the two general questions of WHOQOL-bref, a positive evaluation was observed by UNINTA medical students. The first, which deals with the evaluation of quality of life, it was highlighted that $74.63 \%$ of the participants consider it good or very good. This corroborates with the studies of Bampi et $a l^{13}$ and Alves et $a l^{12}$ who also verified a good or very good evaluation.

The second question, which addresses satisfaction with their health conditions, showed that $57.61 \%$ of medical students were satisfied or very satisfied with their health. These responses were compared with the study conducted by Dias et $a l,{ }^{17}$ who presented this score in $70.2 \%$ of respondents.

Considering the following domains, when the physical domain pattern is observed, we can observe the most common pattern observed in the other scopes analyzed. The physical domain maintained similar results in the first and second semester (3.59 and 3.67 points respectively), followed by a fall in the third semester, with a score of 3.07. As Dyrbye et $a l^{18}$ points out, the reduction of quality of life initially affects the personal domains (eg the physical domain) of the individual, resulting in difficulties in social relationships and substance abuse. In addition to the professional and academic question, low quality of life scores, both physical and mental, were associated with suicidal ideation among medical students in the United States, showing the relevance of the subject and the need for debate in all medical curricula. ${ }^{19}$ Subsequently, the quality of life increases positively until the fifth semester (3.63 points) and remains stable until reaching its peak in the seventh (3.96 points). The analysis of such data can not ignore other factors, extrinsic to the medical course, that compete for the student's quality of life. Negative events, such as the death or serious illness of a close relative, for example, may be related to the decrease in the evaluation by the individual. ${ }^{19}$

In our study, we also observed a significant decrease in the psychological domain in the third and fourth semester of graduation, similar to the study carried out by Alves et al, ${ }^{12}$ which identified a reduction of the psychological domain among the students at the conclusion of the medical course when compared to the students of the course. Hassed et al, ${ }^{20}$ also found a worsening in the psychological domain, using the Whoqol-bref questionnaire in a one-year cohort study of medical students.

The environmental domain was the one that presented the third best scoring score in all domains analyzed, which differs from the study by Chazan \& Campos, ${ }^{11}$ which presented the lowest score in all sociodemographic characteristics. The literature points out that this domain deals with issues such as: health and social care - availability and quality; opportunity to acquire new information and skills; participation in recreation/leisure opportunities; physical environment and transport. $^{21}$ 
When we observe questions related to the social relations domain, we notice that the sum of the scores are better in the last four semesters of the study, compared to the initial four semesters, perceiving an exponential fall in the third semester of graduation, similar to the observed in the other areas. The analysis of this domain involves three questions that evaluate the individual's satisfaction with his social relations (friends, relatives, acquaintances and colleagues), sexual life and the support he receives from his friends. ${ }^{17}$ Probably this low in the first four semesters reflects a phase of adaptation of the students in the first two years, since the entrance in the college is a period of great changes, when these individuals are molded to a new "format of life". It is also believed that a lot of students from the UNINTA University Center medical school come from other cities, it takes some time for emotional and academic adjustment to a "new life" away from family and friends.

The measurement of quality of life generates difficulties due to its broad concept, involving housing, environment, family, work, school, relationships, leisure, ecology and society,

\section{REFERÊNCIAS}

1. The Whoqol Group. The World Health Organization quality of life assessment (WHOQOL): position paper from the World Health Organization. Soc Sci Med. 1995;41(10):1403-9.

2. Cesar BN, Paz IP, Novaes MR. Application of the questionnaire to evaluate the quality of life of medical student in health public school of Brasilia, Brazil. Rev Cienc Med (Campinas). 2012;21(1-6):79-86.

3. Haddad AE, Morita MC, Pierantoni CR, Brenelli SL, Passarella T, Campos FE. Training of health professionals in Brazil: an analysis in the period from 1991 to 2008. Ver Saude Publica. 2010;44(3):383-93.

4. Firth J. Levels and sources of stress in medical students. Br Med J. 1986;292(6529):1177-80.

5. Enns SC, Perotta B, Paro HB, Gannam S, Peleias M, Mayer FB, et al. Medical students' perception of their educational environment and quality of life: is there a positive association? Acad Med. 2016;91(3):409-17.

6. Shareef MA, AlAmodi AA, Al-Khateeb AA, Abudan Z, Alkhani MA, Zebian SI, et al. The interplay between academic performance and quality of life among preclinical students. BMC Med Educ. 2015;15:193.

7. Chazan AC, Campos MR, Portugal FB. Quality of life of medical students at the State University of Rio de Janeiro (UERJ), measured using Whoqol-bref: a multivariate analysis. Ciênc Saúde Coletiva. 2015;20(2):547-56.

8. Santa ND, Cantilino A. Suicídio entre médicos e estudantes de medicina: revisão de literatura. Rev Bras Educ Med. 2016;40(4):77280 .

9. Kamski L, Frank E, Wenzel V. [Suicide in medical students: case series]. Anaesthesist. 2012;61(11):984-8. Article in German.

10. Kluthcovsky AC, Kluthcovsky FA. WHOQOL-bref, um instrumento para avaliar qualidade de vida: uma revisão sistemática. Rev Psiquiatr Rio Gd Sul. 2009;31(3 supl):1-12. aspects not closely linked to health status, but which enable it to be maintained. ${ }^{22}$

\section{CONCLUSION}

A medical career starts long before any physical or diagnostic examination. The selective process, family pressures and the need for self-affirmation of their choices lead the individual, still very young, to deprive himself of various pleasures to achieve a greater goal: to enter the medical course. We conclude that the statistically significant differences found between domains are due to the fact that students, when they enter college, have an enthusiasm that is lost over the years and a desire and search for mutual knowledge that goes away with the routine of the day by day.

Therefore, there is a need for greater concern with the quality of life of medical students and the development of strategies to promote it or to prepare the student to deal with stress during medical training.

11. Chazan AC, Campos MR. Qualidade de vida de estudantes de medicina medida pelo Whoqol-bref - UERJ, 2010. Rev Bras Educ Med. 2013;37(3):376-84.

12. Alves JG, Tenório M, Anjos AG, Figueroa JN. Qualidade de vida em estudantes de medicina no início e no final do curso: avaliação pelo Whoqol-bref. Rev Bras Educ Med. 2010;34(1):91-6.

13. Bampi LN, Baraldi S, Guilherm D, Araújo MP, Campos AC. Qualidade de vida de estudantes de medicina da Universidade de Brasília. Rev Bras Educ Med. 2013;37(2):217-25.

14. Scheffer M, Biancarelli A, Cassenote A. Demografia médica no Brasil-2015.3.ed. São Paulo: Departamento de Medicina Preventiva da Faculdade de Medicina da USP; 2015. 284p.

15. Cardoso FA Filho, Magalhães JF, Silva KM, Pereira IS. Perfil do estudante de medicina da Universidade do Estado do Rio Grande do Norte (UERN), 2013. Rev Bras Educ Med. 2015;39(1):32-40.

16. Fiorotti KP, Renzo RR, Miranda AE. Perfil do estudante de Medicina da Universidade Federal do Espírito Santo, 2007. Rev Bras Educ Med. 2010;34(3):355-62.

17. Dias JC, Libardi MC, Zillo CM, Igarashi MH, Senger MH. Qualidade de vida em cem alunos do curso de medicina de Sorocaba - PUC - SP. Rev Bras Educ Med. 2010;34(1):116-23.

18. Dyrbye LN, Thomas MR, Power DV, Durning S, Moutier C, Massie FS, et al. Burnout and serious thoughts of dropping out of medical school: a multi-institutionalstudy. Acadc Med. 2010;85(1):94-102.

19. Feodrippe AL, Brandão MC, Valente TC. Qualidade de vida de estudantes de medicina: uma revisão. Rev Bras Educ Med. 2013;37(3):418-28.

20. Hassed C, Lisle S, Sullivan G, Pier C. Enhancing th ehealth of medical students: outcomes of na integrated mind-fulness and lifestyle program. Adv Health Sci Educ Theory Pract. 2009;14(3):387-98. 
21. Moreno AB, Faerstein E, Werneck GL, Lopes CS, Chor D. Propriedades psicométricas do instrumento abreviado de avaliação de qualidade de vida da Organização Mundial de Saúde no estudo pró-saúde. Cad Saúde Pública. 2006;22(12):2585-97.
22. Morin E. Educação e complexidade - os setes saberes e outros ensaios. São Paulo: Cortez; 2002.

\section{Como citar:}

Liberato BT, Silva AB, Arcanjo AT, Costa JJ, Hall PR, Santos MD. Analysis of the quality of life of medical students in Sobral - CE. Rev Med UFC. 2020 out-dez;60(4):11-17. 